\title{
Reaction Sequence of Iron Sulfide Minerals in Bacteria and Their Use as Biomarkers
}

\author{
Mihály Pósfai, Peter R. Buseck, Dennis A. Bazylinski, \\ Richard B. Frankel
}

\begin{abstract}
Some bacteria form intracellular nanometer-scale crystals of greigite $\left(\mathrm{Fe}_{3} \mathrm{~S}_{4}\right)$ that cause the bacteria to be oriented in magnetic fields. Transmission electron microscope observations showed that ferrimagnetic greigite in these bacteria forms from nonmagnetic mackinawite (tetragonal FeS) and possibly from cubic FeS. These precursors apparently transform into greigite by rearrangement of iron atoms over a period of days to weeks. Neither pyrrhotite nor pyrite was found. These results have implications for the interpretation of the presence of pyrrhotite and greigite in the martian meteorite ALH84001.
\end{abstract}

Intracellular Fe sulfide crystals are produced by two morphological types of magnetotactic bacteria, one of which is referred to as a magnetotactic many-celled prokaryote (MMP) (1); the other constitutes a morphologically similar group of rod-shaped bacteria (2). Magnetosomes (membranebounded magnetic crystals) in the rodshaped bacteria were originally reported to contain greigite $\left(\mathrm{Fe}_{3} \mathrm{~S}_{4}\right)(3)$, whereas greigite and pyrite $\left(\mathrm{FeS}_{2}\right)(4)$ and, tentatively, pyrrhotite $\left(\mathrm{Fe}_{1-x} \mathrm{~S}\right)(5)$ were identified in magnetosomes in the MMP. Neither pyrrhotite nor pyrite were identified in subsequent studies, however, and the role of pyrite in magnetotactic bacteria is unknown (6). Here, we report observations that elucidate the mechanisms of formation of Fe sulfide minerals in bacteria, and we discuss whether structural features exist to distinguish $\mathrm{Fe}$ sulfide minerals formed in bacteria from those formed inorganically.

Attempts to culture magnetotactic bacteria that produce $\mathrm{Fe}$ sulfides have been unsuccessful. Thus, we collected cells from natural sites where they are abundant, including the water column of Salt Pond, Woods Hole, Massachusetts, and the water and sediments of shallow salt-marsh pools in the Parker River Wildlife Refuge, Row-

M. Pósfai and P. R. Buseck, Departments of Geology and Chemistry/Biochemistry, Arizona State University, Tempe, AZ 85287, USA.

D. A. Bazylinski, Department of Microbiology, Immunology and Preventive Medicine, lowa State University, Ames, IA 50011, USA.

R. B. Frankel, Department of Physics, California Polytechnic State University, San Luis Obispo, CA 93407, USA. ley, Massachusetts, and Sweet Springs $\mathrm{Na}$ ture Preserve, Morro Bay, California. Cells were deposited onto carbon-coated and Formvar-coated $\mathrm{Ni}$ grids for transmission electron microscopy (TEM) (7). Both rodshaped magnetotactic bacteria and the MMP containing Fe sulfide crystals were present in the sediments and water samples collected from these sites (Fig. 1).

We obtained interpretable selected-area electron diffraction (SAED) patterns from between 95 and 100 crystals from several tens of bacteria; the studied crystals were chosen either randomly from the chains of magnetosomes or on the basis of their distinctive morphologies. Consistent with the results of earlier studies (3), most of these crystals were greigite in both types of bacteria. However, we identified several grains of mackinawite. Like greigite, mackinawite was present in both the rod-shaped bacteria and the MMP. A third phase, cubic FeS with the sphalerite structure, also may have been present in these magnetotactic bacteria. We found no pyrite or pyrrhotite.

We only observed mackinawite crystals in relatively fresh (less than a few weeks old) specimens; the mackinawite crystals converted to greigite over time. The two SAED patterns in Fig. 2, A and B, were obtained 10 days apart from the same crystal in a rod-shaped bacterium. The angular relationships and $d$ spacings show that the original mackinawite transformed into greigite. We did not observe any changes in the crystal (either as mackinawite or as greigite) while it was exposed to the electron beam; the transformation occurred during the time the sample was stored between the two studies. These results indicate that mackinawite can be a precursor to greigite in these bacteria.

Conceivably all the bacterial greigite crystals could have formed by solid-state transformation from a precursor phase. Greigite grains characteristically show nonuniform contrast in the TEM images, either because of thickness variations (which would mean that their surfaces are irregular) or because of lattice strain associated with structural defects. Indeed, greigite crystals typically contained stacking faults along their (222) close-packed planes, as was also observed earlier (3). These defects could be individual lamellae that are remnants of the parent mackinawite structure.

Some greigite crystals contain bands parallel to (222) that are several atomic layers thick and show different contrast from the rest of the crystal (Fig. 2D). The spacing of fringes parallel to (222) is $\sim 2.8 \AA$ in the greigite part of the crystal (8), whereas it is $\sim 3 \AA$ within the vertical dark band in the middle of the crystal (the place where the spacing can be best measured), suggesting that the bands (marked by paired arrows in Fig. 2D) have the mackinawite structure and the rest of the crystal has the greigite structure. The SAED pattern (Fig. 2C) is interpretable as a composite of mackinawite

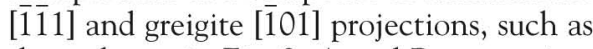
those shown in Fig. 2, A and B, respectively. The two minerals are oriented with respect to one another with $(011)_{\mathrm{m}} / /(222)_{\mathrm{g}}$ and $[110]_{\mathrm{m}} / /[100]_{\mathrm{g}}$, such that the cubic close-packed layers are parallel to one another in the two structures and the S substructure is continuous across the interfaces. The same orientation relation was observed in an experimental study of the mackinawite-to-greigite thermal transformation (9).

Cubic FeS could be a precursor to greig- 
ite and mackinawite. Cubic FeS, which has the sphalerite structure, is known from corrosion products (10) and has been synthesized in aqueous experiments (11). It has not been found in nature, probably because it converts to mackinawite within hours to days when exposed to air (12).

Eight crystals that were studied from a double chain in a rod-shaped bacterium all produced diffraction patterns that could be interpreted as coming either from mackinawite or from cubic FeS (13). The presence of cubic FeS could explain why others (4) identified pyrite in sulfide-producing bacteria. Pyrite is also cubic and has a unit cell with $a=5.4 \AA$, just like cubic FeS; however, the lattice of pyrite is primitive (space group $\mathrm{Pa} 3$ ), whereas that of cubic $\mathrm{FeS}$ is face-centered $(F \overline{4} 3 m)$. Some published single-crystal SAED patterns were interpreted as pyrite [110] projections (2); however, when systematic extinctions are considered, these are [110] projections of an F-centered structure, consistent with cubic FeS. The $d$ spacings in the original reports of sulfides in magnetic bacteria unambiguously show the presence of greigite (Table 1). Non-greigite reflections (boldface items in the last two columns) could belong to either pyrite or cubic FeS. However, pyrite reflections at $2.21,2.43,3.83$, and $5.42 \AA$ were not reported, whereas all cubic FeS spacings can be explained by the non-greigite reflections. The observation of these non-greigite reflections in two independent studies supports our interpretation that cubic FeS is initially present in magnetotactic bacteria.

We have evidence (Fig. 2) that mackinawite magnetosomes convert to greigite; cubic FeS may also convert to mackinawite and then to greigite. Both sequences are consistent with experimental studies showing that cubic FeS converted to mackinawite (11) and that mackinawite converted to greigite $(9,14,15)$, and so the reaction sequences are likely not controlled by the bacteria. The structures of all these phases are based on a cubic close-packed $S$ framework and only differ in the occupancies of Fe sites. Conversions among these structures can occur with the $S$ array preserved, except for a slight contraction of the $S$ substructure as indicated by the spacings of adjacent close-packed layers, which decrease in the sequence cubic FeS $\left(d_{111}=\right.$ $3.12 \AA) \rightarrow$ mackinawite $\left(d_{101}=2.97 \AA\right) \rightarrow$ greigite $\left(d_{222}=2.85 \AA\right)$.

On the basis of high-resolution TEM images that show mixed mackinawite-greigite crystals (such as in Fig. 2D) and planar defects along (222)-type planes of greigite, we propose that the conversion of mackinawite to greigite in the magnetosomes takes place along the close-packed planes,

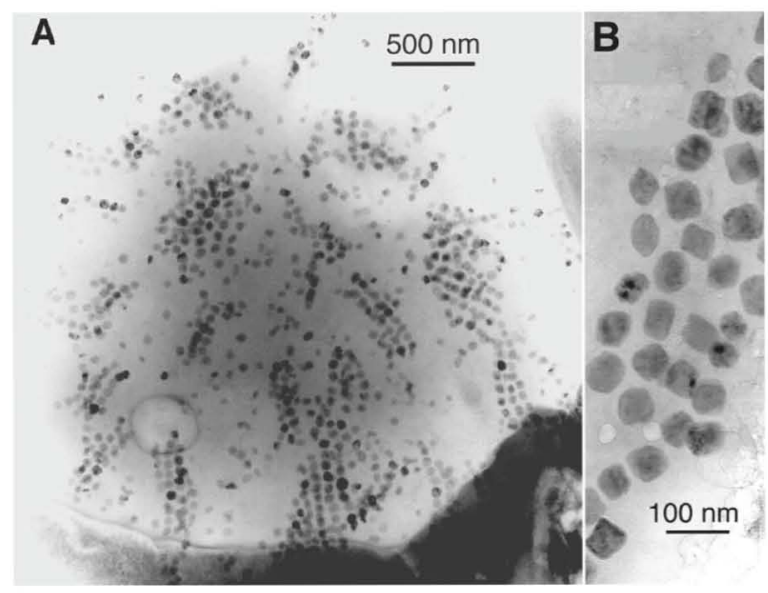

Fig. 1. (A) Fe sulfide crystals in an MMP from Salt Pond, Massachusetts. Individual cells are not discernible in the image. (B) Typical chains of Fe sulfide magnetosomes in an MMP.
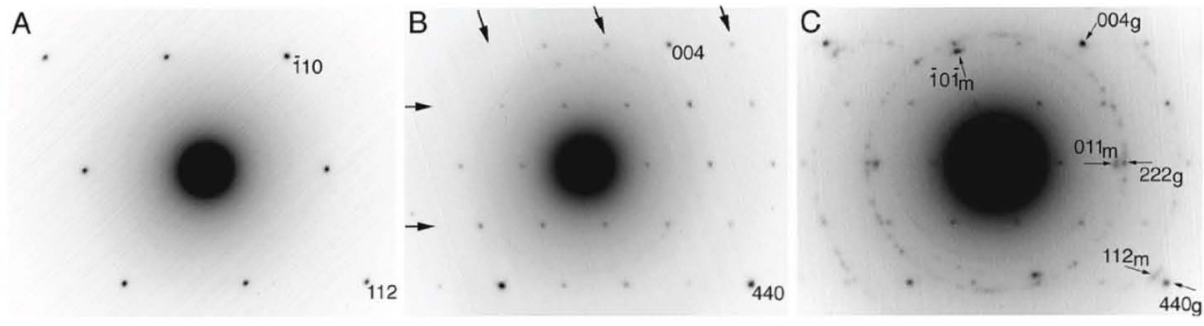

Fig. 2. Conversion of (A) mackinawite into $(\mathbf{B})$ greigite. The SAED patterns in $(A)$ and (B) were obtained from the same magnetosome from a rod-shaped bacterium (from Rowley, Massachusetts), but (B) was recorded 10 days later than (A). Relative to (A), additional reflections appear in $(B)$ along the reciprocal-lattice rows (arrows), and the $d$ spacings of the remaining reflections are also different. (C) SAED pattern and (D) corresponding high-resolution TEM image of a mixed mackinawite/ greigite magnetosome from an MMP (from Salt Pond, Massachusetts). The bands between pairs of arrows probably have the mackinawite structure, whereas the rest of the crystal is greigite.

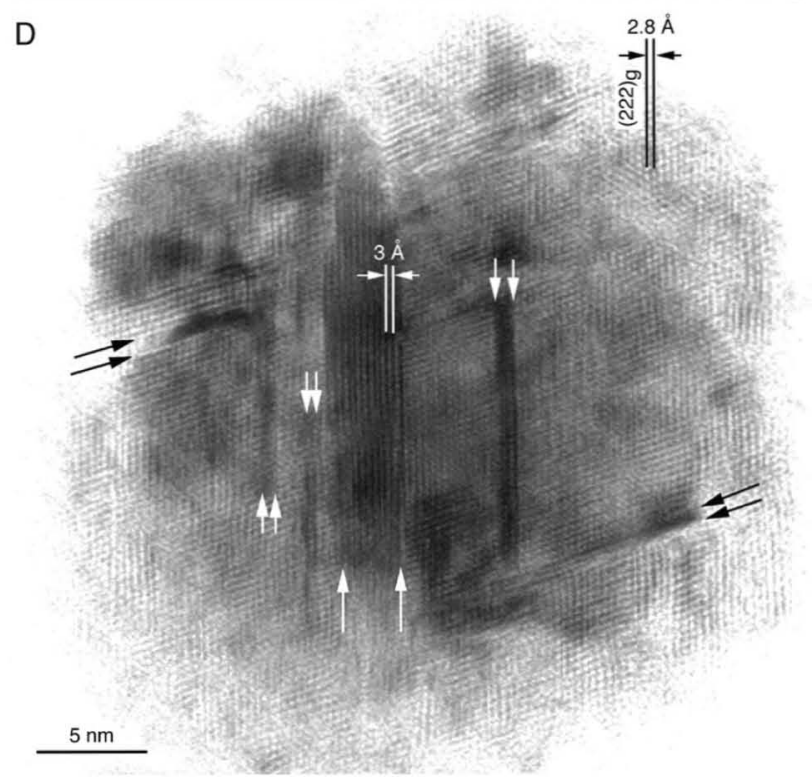

probably through the movement of Fe atoms between neighboring $S$ layers. In the process, half the Fe atoms are oxidized and one-fourth are lost. When the transformation is incomplete, transitional disordered structures result (Fig. 2D).

The composition of the crystal in Fig. 2, $\mathrm{A}$ and $\mathrm{B}$, changed from $\mathrm{Fe}_{0.94} \mathrm{~S}$ to $\mathrm{Fe}_{0.86} \mathrm{~S}$ as it converted from mackinawite to greigite. The direction of the change is consistent with the expected loss of Fe, although this compositional difference is within analytical error (16). The sink for the excess Fe is unclear. According to Lennie et al. (9), the surplus $\mathrm{Fe}$ probably forms amorphous nanophase $\mathrm{Fe}-(\mathrm{OH})$ by reaction with $\mathrm{O}_{2}$ or $\mathrm{H}_{2} \mathrm{O}$. We did not observe any Fe-rich phases other than the magnetosomes in the bacteria; however, Farina et al. (5) reported that amorphous $\mathrm{Fe}$ - and $\mathrm{O}$-rich regions surround sulfide crystals in some bacteria.

Relatively rapid transformation might eliminate mackinawite in samples stored for more than a few weeks. We obtained the mackinawite SAED pattern in Fig. 2A less than a week after collection of the bacteri- 
um that contained the crystal. Thus, the complete conversion from mackinawite to greigite (Fig. 2B) took place within 17 days after sample collection. On the other hand, we found structurally disordered mackinawite-greigite crystals (such as in Fig. 2D) in bacteria that were collected $2 \frac{1}{2}$ months before the TEM study. The complete conversion of these crystals to greigite may have been hindered by their $\mathrm{Cu}$ content (which, in the case of the crystal in Fig. 2D, was 5 atomic \%), whereas the completely converted crystal (Fig. 2, A and B) had no detectable $\mathrm{Cu}$ content.

In one rod-shaped bacterium, all studied crystals within a double chain were either mackinawite or cubic FeS (17). Mackinawite is diamagnetic (18), and at room temperature cubic $\mathrm{FeS}$ is paramagnetic (19). Thus, chain formation is not necessarily a magnetism-related process but is likely controlled by the bacterium independently of whether the grains are magnetic. These observations support the idea that biomineralization and chain assembly are separately controlled in magnetotactic bacteria (20). The precursor $\mathrm{FeS}$ crystals are aligned in the chains such that if they convert to greigite with the $S$ substructure preserved, as described above, then [100] - the likely easy axis of magnetization of greigite (6) will be parallel to the chain.

The conversion of mackinawite to greigite and ultimately to pyrite was observed extracellularly in batch cultures of the dissimilatory, sulfate-reducing bacterium $\mathrm{De}$ sulfovibrio desulfuricans (21). The same reaction sequence apparently occurs at low temperatures in nonbiological reactions over time when excess $S$ or $\mathrm{S}^{2-}$ is present $(21,22)$. Because the MMP and other magnetotactic bacteria that contain Fe sulfides are probably dissimilatory sulfate reducers (23) and these microorganisms live where

Table 1. Identification of bacterial Fe sulfide inclusions from electron diffraction, based on reflections identified in this study $(\bullet)$ in oriented single-crystal SAED patterns and on previous results. Reflections in boldface in the last two columns suggest the presence of cubic FeS and are discussed in the text. Reflections tentatively assigned in this study are denoted by question marks.

\begin{tabular}{|c|c|c|c|c|c|c|c|c|c|}
\hline \multicolumn{8}{|c|}{ Calculated $d$ spacings with corresponding $h k l$ indices } & \multicolumn{2}{|c|}{ Observed $d(\AA)^{\star}$} \\
\hline \multicolumn{2}{|c|}{ Greigite $\left(\mathrm{Fe}_{3} \mathrm{~S}_{4}\right)$} & \multicolumn{2}{|c|}{$\begin{array}{c}\text { Mackinawite } \\
\text { (FeS) }\end{array}$} & \multicolumn{2}{|c|}{ Cubic FeS } & \multicolumn{2}{|c|}{ Pyrite $\left(\mathrm{FeS}_{2}\right)$} & \multirow{2}{*}{$\begin{array}{l}\text { Mann } \\
\text { et al. } \\
\text { (4) }\end{array}$} & \multirow{2}{*}{$\begin{array}{c}\text { Farin } \\
\text { et al } \\
\text { (5) }\end{array}$} \\
\hline$d(\AA)$ & $h k l$ & $d(\AA ̊)$ & $h k l$ & $d(\AA)$ & $h k l$ & $d(\AA \AA)$ & $h k l$ & & \\
\hline 5.72 & $111 \bullet$ & 5.03 & 001 & & & 5.42 & $100 \dagger$ & & 5.68 \\
\hline 3.50 & $220 \bullet$ & & & & & 3.83 & $110 \dagger$ & 3.57 & 3.50 \\
\hline $\begin{array}{l}2.98 \\
2.85\end{array}$ & $\begin{array}{l}311 \bullet \\
222 \bullet\end{array}$ & 2.97 & $101 \bullet$ & 3.12 & $111 \bullet ?$ & 3.13 & 111 & $\begin{array}{l}\mathbf{3 . 1 6} \\
3.06\end{array}$ & $\begin{array}{l}\mathbf{3 . 1 1} \\
2.95 \\
2.86\end{array}$ \\
\hline & & 2.60 & $110 \bullet$ & 2.70 & $200 \bullet ?$ & 2.71 & 200 & 2.69 & \\
\hline 2.47 & $400 \bullet$ & 2.31 & 111 & & & 2.43 & 210 & 2.51 & 2.46 \\
\hline 2.26 & $331 \bullet$ & & & & & 2.21 & 211 & 2.28 & \\
\hline 2.02 & $422 \bullet$ & & & & & & & $\begin{array}{l}2.12 \ddagger \\
2.04\end{array}$ & $2.12 \%$ \\
\hline $\begin{array}{l}1.90 \\
1.90\end{array}$ & $\begin{array}{l}333 \bullet \\
511 \bullet\end{array}$ & $\begin{array}{l}1.84 \\
1.81\end{array}$ & $\begin{array}{l}200 \bullet \\
112 \bullet\end{array}$ & 1.91 & $220 \bullet ?$ & 1.92 & 220 & 1.89 & 1.89 \\
\hline $\begin{array}{l}1.75 \\
1.67\end{array}$ & $\begin{array}{l}440 \bullet \\
531 \bullet\end{array}$ & 1.67 & 003 & & & & & $\begin{array}{l}1.71 \\
1.65\end{array}$ & \\
\hline $\begin{array}{l}1.56 \\
1.51\end{array}$ & $\begin{array}{l}620 \bullet \\
533\end{array}$ & $\begin{array}{l}1.56 \\
1.52\end{array}$ & $\begin{array}{l}211 \bullet \\
103 \bullet ?\end{array}$ & $\begin{array}{l}1.63 \\
1.56\end{array}$ & $\begin{array}{l}311 \bullet ? \\
222 \bullet ?\end{array}$ & $\begin{array}{l}1.63 \\
1.56 \\
1.50\end{array}$ & $\begin{array}{l}311 \\
222 \\
230\end{array}$ & $\begin{array}{l}\mathbf{1 . 6 0} \\
1.55\end{array}$ & $\begin{array}{l}\mathbf{1 . 6 0} \\
1.49\end{array}$ \\
\hline $\begin{array}{l}1.42 \\
1.38 \\
1.38\end{array}$ & $\begin{array}{l}444 \bullet \\
711 \bullet \\
551 \bullet\end{array}$ & 1.41 & 113 & & & 1.45 & 321 & & \\
\hline & & 1.30 & $220 \bullet$ & 1.35 & $400 \bullet ?$ & 1.35 & 400 & 1.35 & \\
\hline
\end{tabular}

*Obtained from single-crystal and ring patterns; $d$ values less than $1.30 \AA$ are omitted because they provide no additional information. †Kinematically forbidden reflections that should appear because of dynamical diffraction. \$This reflection probably corresponds to graphite (100) and arises from graphitization of the amorphous carbon film under the electron beam.

there are relatively high concentrations of $\mathrm{H}_{2} \mathrm{~S}$, the greigite would be expected to eventually convert to pyrite (2). Our study indicates that the same inorganically driven Fe sulfide reaction sequence occurs in the magnetotactic bacteria as in the geological environment, but in bacteria the pathway is truncated at greigite. Such truncation may be under biological control and is beneficial to the cell because it precludes making nonmagnetic pyrite. Not all of the functions of greigite in bacteria are known, but as in bacteria with magnetite magnetosomes, a permanent magnetic dipole moment would presumably enable a motile bacterium to find and maintain an optimal position in a vertical chemical concentration gradient (24).

Our results have implications for the biomineralization of iron sulfides and for terrestrial (and, perhaps, extraterrestrial) iron-sulfur chemistry. They may also be relevant to the origin of life on Earth, in that iron sulfides are thought by some to be energy sources for early life forms (25). Nanometer-scale pyrrhotite and possibly greigite were reported in the martian meteorite ALH84001 and were cited as evidence for ancient life on Mars (26). As we found neither pyrrhotite nor pyrite in terrestrial magnetotactic bacteria, their presence in ALH84001 appears to be irrelevant to the question of possible former biogenic activity on Mars. Greigite, which was also mentioned as a possible phase in ALH84001 (26), is the most abundant sulfide in magnetotactic bacteria and could be the best, although not an unambiguous, indicator of past biogenic activity.

Both greigite and mackinawite convert to smythite in hydrothermal ore specimens (27). When heated above $238^{\circ} \mathrm{C}$ in vacuum, greigite breaks down to pyrrhotite (28); in addition, in many marine sediments mackinawite reacts to greigite and then to pyrite $(15,29)$. Clearly, greigite can transform into at least three different phases, depending on its thermal and chemical environment. Characterization of sulfide minerals and morphologies, together with reliable knowledge about the thermal history of the specimen, is needed to provide useful information about a bacterial origin of $\mathrm{Fe}$ sulfides in extraterrestrial samples.

\section{REFERENCES AND NOTES}

1. M. Farina, H. Lins de Barros, D. Motta de Esquivel, J Danon, Biol. Cell. 48, 85 (1983); F. G. Rodgers et al., Arch. Microbiol. 154, 18 (1990).

2. D. A. Bazylinski, R. B. Frankel, A. J. Garratt-Reed, S Mann, in Iron Biominerals, R. B. Frankel and R. P. Blakemore, Eds. (Plenum, New York, 1990), pp. 239-255.

3. B. R. Heywood, S. Mann, R. B. Frankel, Mater. Res. Soc. Symp. Proc. 218, 93 (1991).

4. S. Mann, N. H. C. Sparks, R. B. Frankel, D. A. Bazylinski, H. W. Jannasch, Nature 343, 258 (1990). 
5. M. Farina, D. M. S. Esquivel, H. G. P. Lins de Barros, ibid., p. 256.

6. D. A. Bazylinski and B. M. Moskowitz, Rev. Mineral. 35, 181 (1997).

7. After deposition on the TEM grids, the bacterial cells were dried in air and were kept in a grid box in air before and between TEM studies. We used a JEOL 2000FX TEM operated at a 200-kV accelerating voltage and equipped with a double-tilt $\left( \pm 30^{\circ}, \pm 45^{\circ}\right)$ goniometer stage. TEM images were used to observe particle morphologies and structural defects. Compositions were determined by energy-dispersive $\mathrm{x}$-ray spectrometry with an attached ultrathin-window KEVEX detector. Experimental $k$-factors for thin-film analysis were determined for $\mathrm{Fe}$ and $\mathrm{Cu}$ using pyrite and $\mathrm{Cu}$ sulfide standards. The structures of Fe sulfides were identified using single-crystal SAED by tilting the crystals into zone-axis orientations.

8. There is uncertainty in the measured $d$ spacings as a result of structural disorder in almost every part of this crystal.

9. A. R. Lennie et al., Am. Mineral. 82, 302 (1997).

10. R. De Médicis, Science 170, 1191 (1970).

11. J. B. Murowchick and H. L. Barnes, Am. Mineral. 71, 1243 (1986)

12. J. B. Murowchick, Geol. Soc. Am. Progr. Abstr. 21 , A120 (1989).
13. On the basis of the geometries of SAED patterns that were obtained from these crystals, they could be either [001], [111], [131], [313], and [232] projections of mackinawite or [001], [110], [112], [123], and [114] projections of cubic FeS, respectively (these patterns are not shown in the figures). The $d_{200}$ spacings of cubic FeS and the crystallographically corresponding $d_{110}$ spacings of mackinawite are 2.7 and $2.6 \AA$, respectively; the observed reflections have $d$ values closer to cubic $\mathrm{FeS}$ than to mackinawite.

14. D. T. Rickard, Stockholm Contrib. Geol. 20, 55 (1969).

15. M. A. A. Schoonen and H. L. Barnes, Geochim Cosmochim. Acta 55, 1505 (1991).

16. In the case of these small crystals embedded in bacterial cells, the analytical error is estimated to be about 0.1 formula unit Fe.

17. One month after sample collection, these crystals were still mackinawite or cubic FeS; they also contained a few atomic percent $\mathrm{Cu}$, just like the disordered mackinawite-greigite magnetosomes. The cel was collected from Salt Pond, MA.

18. E. F. Bertaut, P. Burlet, J. Chappert, Solid State Commun. 3, 335 (1965).

19. M. Wintenberger, B. Srour, C. Meyer, F. HartmannBoutron, Y. Gros, J. Phys. (Paris) 39, 965 (1978).
20. D. A. Bazylinski et al., Appl. Environ. Microbiol. 61, 3232 (1995).

21. D. T. Rickard, Stockholm Contrib. Geol. 20, 67 (1969).

22. R. A. Berner, Am. J. Sci. 265, 773 (1967).

23. E. F. DeLong, R. B. Frankel, D. A. Bazylinski, Science 259, 803 (1993).

24. R. B. Frankel, D. A. Bazylinski, M. S. Johnson, B. L. Taylor, Biophys. J. 73, 994 (1997).

25. G. Wächtershäuser, Syst. Appl. Microbiol. 10, 207 (1988); Microbiol. Rev. 53, 452 (1988); R. J. P. Williams, Nature 343, 213 (1990).

26. D. S. Mckay et al., Science 273, 924 (1996).

27. R. E. Krupp, Eur. J. Mineral. 6, 265 (1994)

28. B. J. Skinner, R. C. Erd, F. S. Grimaldi, Am. Mineral 49, 543 (1964)

29. W. Morse, F. J. Millero, J. C. Cornwell, D. Rickard, Earth Sci. Rev. 24, 1 (1987).

30. We thank J. B. Murowchick, H. Hartman, and I. Dódony for helpful discussions, B. Howes and D. R. Schlezinger for help with sample collection, and W. H. Fowle for suggestions in the manipulation of magnetotactic microorganisms. Supported by grants from NSF and NASA. Electron microscopy was performed at the Center for High-Resolution Electron Microscopy at Arizona State University. 